\title{
Hematological Characterization of Beta Thalassemia in Sudanese Patients
}

\author{
Rabab Hassan E1* and Sanaa Elfatih $\mathrm{H}^{2}$ \\ ${ }^{1}$ Department of Hematology and Immunohematology, University of Gezira, Sudan \\ ${ }^{2}$ Assistant professor, University of Gezira, Sudan
}

*Corresponding author: Rabab Hassan Elshaikh, Department of Hematology and Immunohematology, Faculty of Medical Laboratory Sciences, University of Gezira, Sudan; Email: rababhassan1892@gmail.com

\section{Research Article \\ Volume 4 Issue 1}

Received Date: November 28, 2019

Published Date: January 10, 2020

DOI: $10.23880 /$ hij-16000150

\section{Abstract}

Thalassemia is common inherited disorder among humans, and they represent a major public health problem in many areas of the world. The study aimed to measurement of hematological characterization of beta thalassemia in Sudanese patients. Blood samples from 61 beta thalassemic patients were collected after written consent form obtained from all participants. The frequency of Adults ( $>18$ years) were 45 (73.8\%), and Children's ( $<18$ years), were 16 (26.2\%) the frequency of male was $27(44.3 \%)$ and 34 were females (55.7\%). Hemoglobin estimation and red cell indices were carried out using the automatic blood cell counter Sysmex KX21N. The results showed Hb and RBCs indices were vared between mild to moderate and severe decreasing, Hemoglobin concentration ( $\mathrm{Hb}$ ) with the mean value of $9.6 \mathrm{~g} / \mathrm{dL}$, with minimum value of $6.1 \mathrm{~g} / \mathrm{dL}$ and maximum of $11.9 \mathrm{~g} / \mathrm{dL}$, while RBCs was increased in all patients, mean value $5.2 \mathrm{c} / \mathrm{L}$, Mean corpuscular volume (MCV) mean was $58.9 \mathrm{fL}$, hematocrit was 30.4, mean corpuscular hemoglobin (MCH) $18.8 \mathrm{pg}$, mean corpuscular hemoglobin concentration (MCHC) was $31.7 \mathrm{pg}$ and RDW was $18.8 \%$. The method used for hemoglobin electrophoresis was cappilary electrophoresis, $\mathrm{Hb}$ pattern shows increased $\mathrm{HbA} 2$ and $\mathrm{HbF}$, the mean of $\mathrm{HbA}$ is $78.3 \%$, $\mathrm{HbF}$ is $2.3 \%$, and $\mathrm{HbA} 2$ is $6.5 \%$ with the min value of $3.6 \%$ and max of $12.2 \%$. While the mean of serum iron was $82.75 \mathrm{ug} / \mathrm{dL}, 7$ patients showed low level, 19 high level and 35 was normal level. Comparison of hematological analysis (HbA2) in thalassemic patients coexisted with Iron deficiency and without result was insignificant difference $(p=0.645)$ this result disagree with references that say iron deficiency masking HbA2. Nevertheless the association between $\mathrm{HbA2}$ and $\mathrm{HbF}$ revealed a statistically significant difference $(\mathrm{p}<.013)$ and $\mathrm{HbA2}$ with $\mathrm{Hb}$ was insignificant $(\mathrm{p}=.260)$.

Keywords: Thalassemia; RBCs indices; Hb electrophoresis; CBC; Iron; Sudan

Abbreviations: CBC: Complete Blood Count; Hb: Hemoglobin; MCHC: Mean Corpuscular Hemoglobin
Concentration; MCV: Mean Corpuscular Volume; HbA2: Hematological A2; MCH: Mean Corpuscular Hemoglobin; 
RDW: Red Cell Distribution Width; TIF: Thalassemia International Federation.

\section{Introduction}

Thalassemia is a Mendelian autosomal recessive heritable blood disorder it's a group of genetically determined microcytic, hypochromic anemia's resulting from a decrease in synthesis of one or more globin chains in the hemoglobin molecule [1]. The most common types are alpha and beta thalassemia according to which globin chain is reduced [2]. Beta thalassemia is classified into three types depending on the severity of symptoms: thalassemia major also known as Cooley's anemia [3,4]. Thalassemia intermediate and thalassemia minor, thalassemia major is more severe. The signs and symptoms of thalassemia major appear within the first 2 years of life, Children develop life-threatening anemia, and they do not gain weight and grow at the expected rate (failure to thrive) and may develop yellowing of the skin and whites of the eyes (jaundice) [5]. Affected individuals may have an enlarged spleen, liver, heart, and their bones may be misshapen. Some adolescents with thalassemia major experience delayed puberty. Many people with thalassemia major have such severe symptoms that they need frequent blood transfusions to replenish their red blood cell supply over time, an influx of iron-containing hemoglobin from chronic blood transfusions can lead to a buildup of iron in the body, resulting in liver, heart, and hormone problems. Thalassemia intermedia are milder than thalassemia major [6]. The signs and symptoms of thalassemia intermedia appear in early childhood or later in life. Affected individuals have mild to moderate anemia and may also have slow growth and bone abnormalities [7]. The disorder may occur in the homozygous or heterozygous state. Heterozygotes may be asymptomatic but Homozygotes typically have a severe, often fatal, disease. It involves increased (HbA2) and decreased production of normal adult hemoglobin $(\mathrm{Hb} A)$, the predominant type of hemoglobin from soon after birth until death [8]. Mostly the patients are diagnosed on routine blood examination. Beta Thalassemia carrier it is commonly not diagnosed until adolescence or adult life, and may be detected in a routine hematological screening examination. The red Cell indices, Hb Electrophoresis and molecular studies give more reliable diagnosis. In thalassemia trait MCV and MCH are low while MCHC is marginally reduced or normal. Hemoglobin electrophoresis and molecular study is essential for definite diagnosis of $\beta$-thalassemia cases. Normally $\mathrm{Hb} \mathrm{A} 2$ is less than $3.2 \%$ but in Beta- thalassemia trait it is more than $3.5 \%$ [9].

\section{Materials and Methods}

Across-sectional descriptive study was carried out to detect hematological characterization of BetaThalassemia Sudanese patient in Khartoum State Sudan, during the period of July 2017 to July 2019. From each patient, $2.5 \mathrm{ml}$ of venous blood sample was collected in sterile EDTA container. The blood samples were analyzed for Complete blood count (CBC) using the automated hematology analyzer Sysmex KX21N, (manufactured by Sysmex corporation Kobe, Japan) within 24 hours of blood collection. On the same day itself the blood samples were screened for Haemoglobinopathies by $\mathrm{Hb}$ electrophoresis method (Sebia, France) [10]. The inclusion criteria Patients were diagnosed as Beta thalassemia, availability of patient demographic data and laboratory reports, (CBC, Hemoglobin electrophoresis, and peripheral blood picture, Iron studies), Patients not diagnosed as Beta-thalassemia or coexisted with other hemoglobin variants or with other hematological malignancy excluded from the study. Permission of this study was obtained from the local authorities in the area of the study. The objective of the study explained to all individuals participating in this study. An informed written consent obtained from all participants.

\section{Results}

Out of 61 beta-thalassemic patients the frequency of Adults ( $>18$ years) was $45(73.8 \%)$, and $16(26.2 \%)$ was Childrens (18 years) and the frequency of male to female was 27 of the patients were males (44.3\%) and 34 were females (55.7\%) as shown in (Table 1) Hemoglobin estimation and red cell indices were carried out using the automatic blood cell counter Sysmex KX21N. The results obtained were as follow: Hemoglobin concentration ( $\mathrm{Hb})$ with the mean value of $9.6 \mathrm{~g} / \mathrm{dL}$, with minimum value of $6.1 \mathrm{~g} / \mathrm{dL}$ and maximum of $11.9 \mathrm{~g} / \mathrm{dL}$, while $\mathrm{RBCs}$ was increased in all patients with mean value of 5.2c/L, Mean corpuscular volume (MCV) mean was $58.9 \mathrm{fL}$, hematocrit was 30.4, mean corpuscular hemoglobin $(\mathrm{MCH}) 18.8 \mathrm{pg}$, mean corpuscular hemoglobin concentration (MCHC) was $31.7 \mathrm{pg}$ and RDW was $18.8 \%$, as shown in (Table 2). The method used for hemoglobin electrophoresis was cappilary electrophoresis the $\mathrm{Hb}$ pattern shows increased $\mathrm{HbA} 2$ and $\mathrm{HbF}$, the mean of $\mathrm{Hb} \mathrm{A}$ is $78.3 \%, \mathrm{HbF}$ is $2.3 \%$, and $\mathrm{HbA} 2$ is $6.5 \%$ with the min value of $3.6 \%$ and max of $12.2 \%$ as shown in (Table 3). The mean of serum iron was $82.75 \mathrm{ug} / \mathrm{dL}, 7$ patients showed low level, 19 high level and 35 was normal level, (Table 4) and (Figures 1-3). 


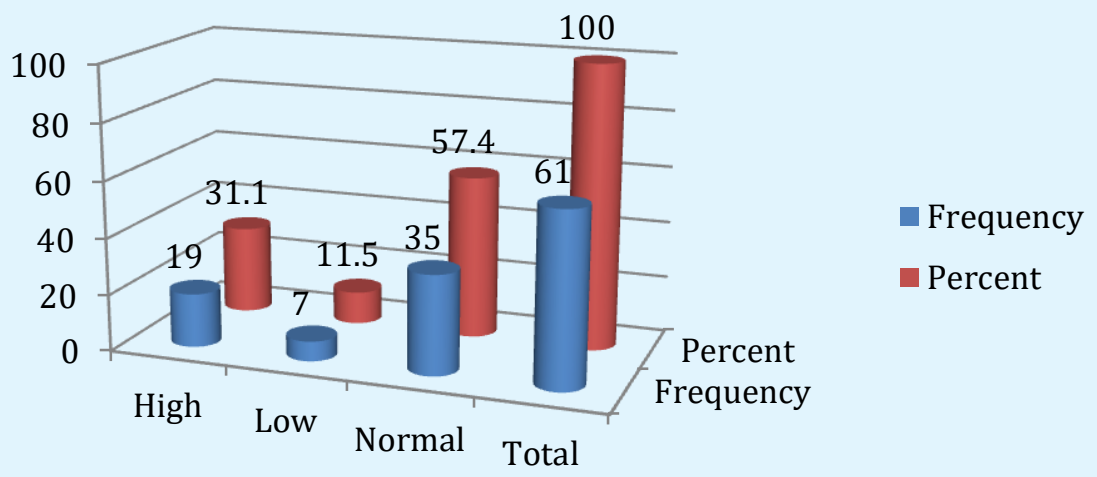

Figure 1: Frequency of Iron level in study group.

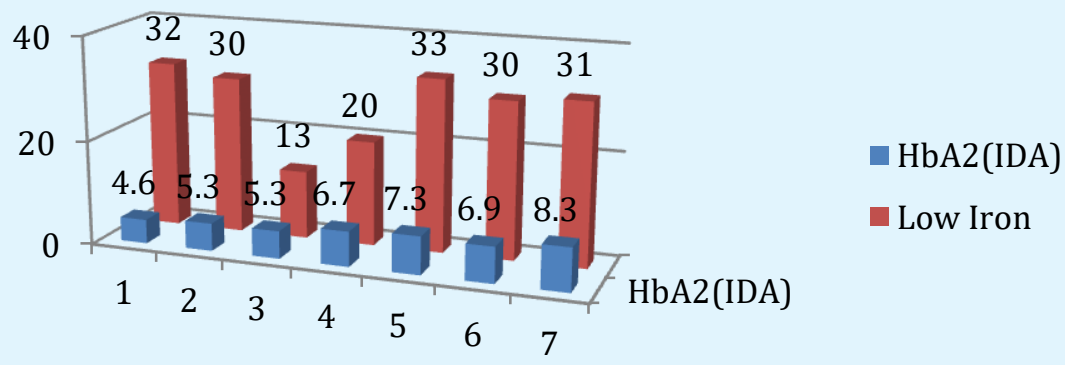

Figure 2: $\mathrm{HbA} 2$ in thalassemic patients co-existed with iron deficiency.

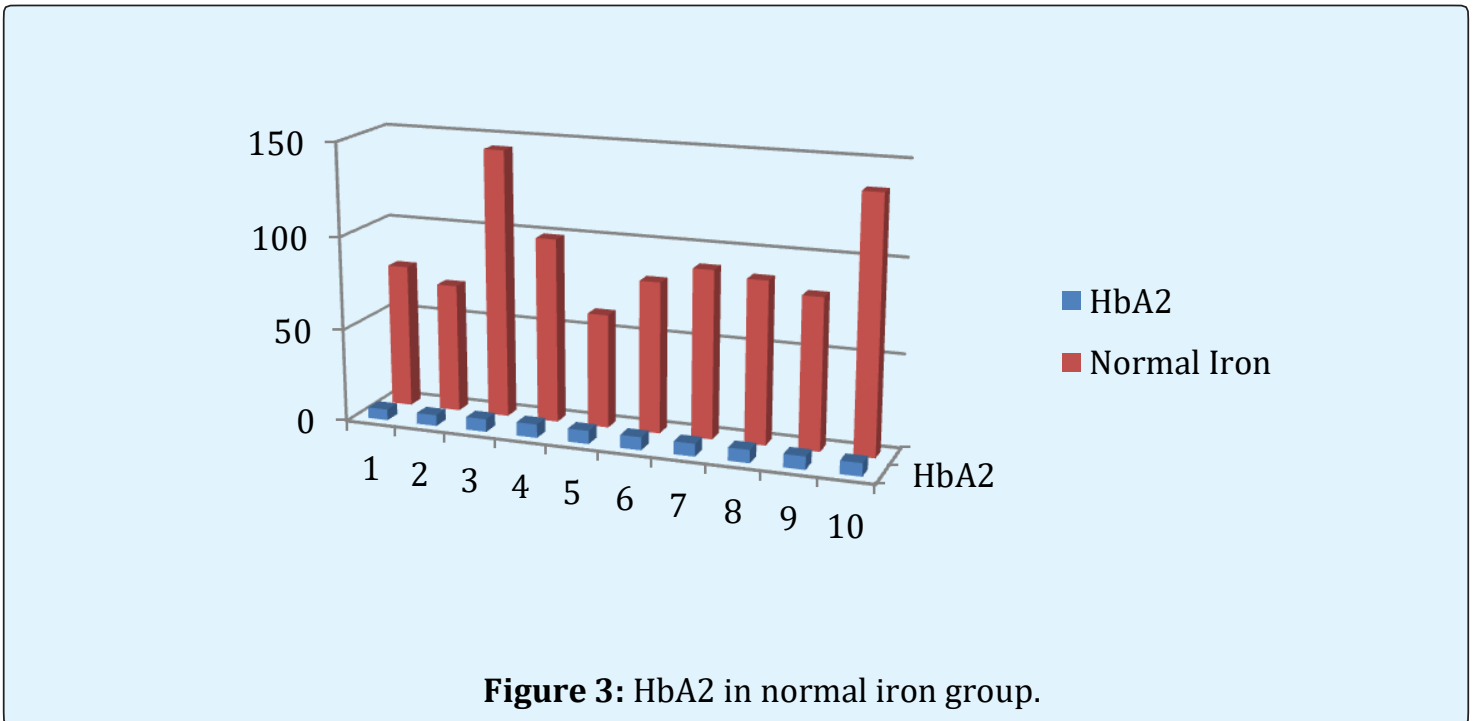




\begin{tabular}{|c|c|c|}
\hline & Frequency & Percent \\
\hline Gender & & 44.3 \\
\hline Male & 27 & 55.7 \\
\hline Female & 34 & \\
\hline Age group(y) & & 26.2 \\
\hline$<18$ & 16 & 73.8 \\
\hline$>18$ & 45 & \\
\hline
\end{tabular}

Table 1: Gender and Age distribution in the study group.

\begin{tabular}{|c|c|c|c|c|c|c|c|}
\hline Parameters & Hb/g/d & HCT & RBCs & MCV & MCH/pg & MCHC/pg & RDW\% \\
\hline Mean & 9.618 & 30.364 & 5.197 & 58.882 & 18.761 & 31.657 & 18.825 \\
\hline Std. Deviation & 1.3214 & 3.6247 & 0.7394 & 6.5545 & 2.9306 & 1.7615 & 2.9644 \\
\hline Minimum & 6.1 & 18.8 & 3.2 & 44.2 & 13.3 & 27.2 & 12.5 \\
\hline Maximum & 11.9 & 36.2 & 6.7 & 76.4 & 27.2 & 35.6 & 23.3 \\
\hline
\end{tabular}

Table 2: Mean and standard deviation of $\mathrm{Hb}$ and RBCs indices in the study group.

\begin{tabular}{|c|c|c|c|}
\hline Hb electrophoresis parameters & HbA2/\% & HbF/\% & HbA/\% \\
\hline Minimum & 3.6 & 0.4 & 70.1 \\
\hline Maximum & 12.2 & 10.4 & 92.7 \\
\hline Mean & 6.498 & 2.277 & 78.289 \\
\hline Std. Deviation & 1.3895 & 1.9511 & 3.2221 \\
\hline
\end{tabular}

Table 3: Hb electrophoresis pattern in thalassemic patients.

\begin{tabular}{|c|c|}
\hline & Iron result \\
\hline Mean & 82.75 \\
\hline Std. Deviation & 29.112 \\
\hline
\end{tabular}

Table 4: Mean and standard deviation of serum iron in study population.

\section{Discussion}

For 61 beta-thalassemic patients, Hemoglobin estimation and red cell indices were carried out using the automatic blood cell counter Sysmex KX21N. The results obtained were; overall mean haemoglobin concentration (Hb) was decreased $9.6 \mathrm{~g} / \mathrm{dL}$. Red blood cell count (RBCs) $5.19 \times 1012$ cell/L was found to be raised. Red blood cell indices were found to be low (packed cell volume mean cell volume (MCV) $58.9 \mathrm{fL}$, mean cell haemoglobin (MCH) $18.8 \mathrm{pg}$, mean cell haemoglobin concentration (MCHC) $31.7 \mathrm{~g} / \mathrm{dL}$, red cell distribution width (RDW) 18.8)this results agreed with several studies in literature Eg. Galanello, et al. Tahir, et al. Idit, et al. [11-13] specially with Dr. Sana [14] literature. Also this study agreed with the data mentioned in thalassemia international federation (TIF). Hb electrophoresis was measured by capillary electrophoresis results shows mean of $\mathrm{HbF}$ is $2.3 \%$ which was high, and $\mathrm{HbA} 2$ is $6.5 \%$ with the $\min$ value of $3.6 \%$ and max of $12.2 \%$ also shows significant increase which agreed with several studies eg. Sana, $[14,15]$. The mean of serum iron was $82.75 \mathrm{ug} / \mathrm{dL}, 7$ patients showed low level, 35 was normal level and 19 high levels those are mainly due to blood transfusion, unfortunately data of blood transfusion was missing in this study, Many studies shows similar result unless in recurrent transfused thalassemic patients levels are much higher. Comparison of hematological analysis (HbA2) in thalassemic patients coexisted with Iron deficiency and without result was insignificant difference $(p=0.645)$ this result disagree with many references that say Iron deficiency masking $\mathrm{HbA2}$. Nevertheless the association between $\mathrm{HbA} 2$ and $\mathrm{HbF}$ revealed a statistically significant difference $(p<.013)$, that means there is positive correlation between $\mathrm{HbA} 2$ and $\mathrm{Hb}$ F. and the correlation between $\mathrm{HbA} 2$ with $\mathrm{Hb}$ was insignificant ( $\mathrm{p}=.260$ ) [1618].

\section{Conclusion}

This study was detected the hematological characterization of beta thalassemia the results obtained for $\mathrm{Hb}, \mathrm{RBCs}$ indices, and $\mathrm{Hb}$ electrophoresis were agreed with several studies, In areas where modern equipment's for diagnosis are not available, the red cell indices and Hemoglobin electrophoresis gives more reliable diagnosis 
for beta thalassemia and molecular study provide definitive diagnosis. Since there are no symptoms for beta thalassemia trait it's very important to discover at early as possible from routine hematological test to prevent beta thalassemia major offspring's.

Acknowledgements: The authors are grateful to Staff of pediatric teaching hospital for helping in sample collection. Special thanks to my family for their support, encouragement and patient.

\section{References}

1. Hoffbrand AV, Catovsky D, Edward GD (2005) Postgraduate haematology, $5^{\text {th }}$ (Edn.), United Kingdom, Blackwell publishing, 1: 85-103.

2. David J Weatherall (1999) Genetic disorder of hemoglobin, Postgraduate haematology, $5^{\text {th }}$ (Edn.), pp: 91-119.

3. Thomas B Cooley (1945) Disorders of the blood Brennemann. Practice of pediatrics, Hagerstown Md., WF Prior Company, Inc, 3.

4. Whipple GH, Bradford WL (1936) Mediterranean disease-thalassemia (Erythroblastic anemia of cooley); associated pigment abnormalities stimulating hemochromatosis. J Pediatric 9(3): 279311.

5. Piomelli S, Loew T (1999) Management of thalassemia major (Colley's Anemia). Hematol Oncol Clin North Am 5(3): 557-569.

6. Hassan M Yaish, Robert J Arceci (2009) Pediatric thalassemia intermedia 29: 9.

7. Raffaella Origa (2015) Beta-Thalassemia. Gene Reviews.

8. Thein SL (2008) Genetic modifiers of the betahaemoglobinopathies. Br J Haematol 141(3): 357 366.

9. De Gruchys (1989) Clinical Hematology in Medical Practice $5^{\text {th }}$ (Edn.), In: Frank Firkin, et al.
International Federation, Guidelines to the Clinical Management of Thalassemia. 2000 (World Bank 2006, report of a joint WHO-March of Dime meeting 2006), (TIF).

10. SEBIA, SRC Department parc technologique Leonard de Vinci CP 8010 Lisses-91008 EVRY Cedex -France.

11. Galanello R, Melis MA, Ruggeri R, Addis M, Scalas MT, et al. (1979) Beta0 thalassemia trait in Sardinia. Hemoglobin 3(1): 33-46.

12. Tahir Jameel, Mukhtar Baig, Liaz Ahmed, Muhammad Barakat, Motlag Alkhamaly (2017) Differentiation of beta thalassemia trait from iron deficiency anemia by hematological indices. Pak J Med Sci 33(3): 665-669.

13. Idit LR, Boaz L, Guy K, Carina L, Luci Z (2018) Detection of thalassemia carriers by red cell parameters Obtained from Automatic Counters using Mathematical Formulas. Mediterr J Hematol Infect Dis 10(1): e2018008.

14. Sana E (2013) Molecular Genetics of Beta Thalassaemia in Sudan.

15. Mohammed Omer (2014) A Screening of hemoglobinopathy in Bija tribes and other minor groups living in Port Sudan. JMLD 5(4): 35-40.

16. Androulla Eleftheriou, Micheal Angastiniotis (1996) Thalassemia international federation, 1986, report of a joint WHO, Hematological indices most commonly found in patients with thalassemia, Hemoglobinopathesis B-thalassemia booklet 1, ISBN 24(11): 978-996.

17. Thein SL (2005) Pathophysiology of $\beta$ thalassemia-A guide to molecular therapies. Hematology Am Soc Hematol Educ Program pp: 31-37.

18. Abbas MY (2014) Haematological parameters in Sudanese children with sickle cell disease. American Journal of Research Communication 2(2): 20-32. 